\title{
Finansal Piyasalar, Rekabetçilik, İnovasyon ve Üniversite-Sanayi İşbirliği: G20 Örneği
}

\author{
Hayri ABAR ${ }^{1}$
}

$\ddot{\mathrm{O} z}$

Ülkelerin ekonomik göstergeleri arasında olan hisse senedi piyasalarına küresel rekabet, üniversite - sanayi işbirliği, küresel inovasyon ve ekonomik büyüklük gibi faktörlerin etkisi günümüzde ilgi çeken konulardır. Çalışmada borsa endeksi (BE), küresel rekabet endeksi (RE) ve küresel rekabet endeksini oluşturan alt değişkenlerden inovasyon kapasitesi endeksi (İKE), kişi başına gayrisafi yurtiçi hâsıla (GSYH) ve araştırma geliştirme faaliyetlerinde üniversite sanayi işbirliği endeksi (ÜSİE) değişkenleri kullanılmıştır. Analizler G20 ülkelerine ait olan 2007 - 2017 yılları arası panel veri seti ile gerçekleştirilmiştir. Westerlund Eşbütünleşme Testi sonuçlarına göre BE ile RE arasında uzun dönem ilişki söz konusu değildir. Panel ARDL modeli sonuçlarına göre ise BE ile İKE, ÜSİE ve GSYH arasında uzun dönem ilişki tespit edilmiştir. Analiz sonuçları, dışsal şokların yani olağandışı durumların etkisinin bir dönemde yaklaşık \%71'inin hata düzeltme mekanizması ile ortadan kalktı̆̆ını göstermektedir. Bu değişkenlerin tamamı uzun dönemde BE'ni olumlu etkilemektedir. En fazla etki ise ÜSİE için elde edilmiştir. Üniversitede üretilen bilimin topluma yansıtılmasının ve sanayide kullanılmasının ülke ekonomisi üzerinde olumlu etkileri bulunmaktadır.

Anabtar Kelimeler: Finansal Piyasalar, Rekabetçilik, İnovasyon, Eşbütünleşme

\section{Financial Markets, Competitiveness, Innovation and University-Industry Cooperation:} G20 Case

\section{Abstract}

The effects of factors such as global competition, university-industry collaboration, global innovation and economic development on stock markets which are among the economic indicators of countries are of interest today. Stock market index (BE), global competition index (RE) and the variables used in obtaining global competition index (RE) which are innovation capacity index (IKE), per capita gross domestic product (GDP), university industry cooperation index in research and development activities (UTI) were used in this paper. The analyses were carried out with the panel data set between 2007 and 2017, which belongs to G20 countries. There is no long-term relationship between $\mathrm{BE}$ and $\mathrm{RE}$ according to Westerlund Cointegration Test results. According to the results of the panel ARDL model, a long-term relationship was found between and IKE, UTI and GDP. The results of the analysis show that approximately $71 \%$ of the effects of external shocks, i.e. unusual conditions, have disappeared with error correction mechanism in a period. All of these variables have a positive effect on BE for the long term. The maximum effect was obtained for ÜSİE. Contributions of university education to the society and its application in industry have positive effects on the country's economy.

Key Words: Financial Markets, Competitiveness, Innovation, Cointegration

\section{Atıf İçin / Please Cite As:}

Abar, H. (2020). Finansal piyasalar, rekabetçilik, inovasyon ve üniversite-sanayi işbirliği: G20 örneği. Manas Sosyal Arastırmalar Dergisi, 9(2), 1031-1045.

Geliş Tarihi / Received Date: 12.03.2019

Kabul Tarihi / Accepted Date: 26.07.2019

\footnotetext{
${ }^{1}$ Dr. Öğr. Üyesi - Gaziantep Üniversitesi, İktisadi ve İdari Bilimler Fakültesi, hayriabar@gmail.com ORCID: 0000-0002-2043-6747
} 


\section{Giriş}

Ülkelerin ekonomik göstergeleri arasında gösterilen hisse senedi piyasaları ile ilgili endeksler arasında bir ilişkinin var olup olmadığına, var ise hangi yönlü olduğuna, elde edilecek ilişkinin politika yapıcılar, yatırımcılar ve işletmeler için yararlı bir bilgi olup olmayacağına dair konular özellikle finansal ekonometristlerin ilgisini cezbetmektedir. Küresel rekabet, üniversite-sanayi işbirliği, küresel inovasyon ve ekonomik gelişme konuları literatürde özellikle son dönemde sıklıkla karşılaşılan kavramlardır. Dünya Bankas1, OECD ve INSEAD (Institut Européen d'Administration des Affaires - Avrupa Issletme Enstituisiu) gibi dünyanın önde gelen kurumlar tarafindan oluşturulan bu kavramlarla ilgili endeksler içerikleri itibariyle birçok bilimsel çalışmada kullanılmaktadır. Günlük yaşantımız içerisinde iyiden iyiye yer edinen küreselleşme ile birlikte bu tür endeksler de bilgiye doğrudan erişebilmek adına politika yapıcılar, işletmeler, yatırımcılar ve daha birçok paydaş için elde edilmesi zor olan bilgileri tek bir rapor içerisinde sunmaktadir.

Bu çalışmada Türkiye'nin de içerisinde yer aldığ1 G20 ülkelerine ait 2007 - 2017 yllları arası veriler kullanılarak küresel rekabet endeksi, inovasyon kapasitesi endeksi, üniversite sanayi işbirliği endeksi ve ekonomik büyüme ile ilgili ülke borsalarının endeksleri arasındaki ilişki incelenmektedir. Bu bağlamda, çalş̧mada öncelikle küresel rekabet endeksi, üniversite-sanayi işbirliği endeksi ve küresel inovasyon endeksi ile ilgili bilgiler sunulacaktır. Çalışma literatür taraması, yöntem ve bulgular ile devam edecek ve sonuç kısmı ile sonlandırlacaktır.

\section{Küresel Rekabet Endeksi}

Rekabet edebilirlik, bir ülke ekonomisinin serbest ticaret ve piyasa koşulları altında, ulusal ve uluslararası piyasaların taleplerini karşılayan mal ve hizmetleri üretebilme gücüne hangi ölçüde sahip olduğunu açılayan bir kavramdır. Ekonomilerin rekabet edebilirliği, üretim faktörlerinin etkin ve verimli kullanılmasılyla ifade edilmektedir. Rekabet edebilirlik bir ülkenin verimlilik ve etkinlik kapasitesini ortaya koyan en önemli faktörlerden biridir. Bu kapsamda Dünya Ekonomik Forumu tarafindan rekabet edebilirlik; bir ülkenin üretkenlik seviyesini gösteren kurumların, politikaların ve faktörlerin bir birleşimi olarak tanımlanmaktadır (Küresel Rekabetçilik Raporu 2014-2015).

Küresel Rekabet Endeksi ülkelerin rekabet edebilirliklerini, etkinliklerini ve verimliliklerini belirleyen faktörleri farklı ağırık ortalamaları ile ortaya koymaktadır. Endeks kapsamında yayınlanan raporların temel amac1, ülkelerin rekabet düzeylerini etkileyen unsurları belirleyerek ilgili ülkenin güçlü ve zayıf yanlarını ortaya çıkarmak ve politika yapıcılara, yatırımcılara, işletmelere ve kamuya yol gösterici olmaktır. Dünya Ekonomik Forumu (WEF), tarafindan 2005 yllından beri her yil yayınlanan endeks ulusal rekabet edebilirliğin mikroekonomik ve makroekonomik temellerini ölçen kapsamlı bir araçtır (Dünya Ekonomik Forumu Küresel Rekabetçilik Endeksi, 2017).

\section{Üniversite - Sanayi İşbirliği}

Teknolojik ve bilimsel ilerlemenin önemi, endüstriyel toplumdan küresel düzeyde bilgi toplumuna geçişte kendini göstermektedir. Bilgiye dayalı toplumlarda, üniversiteler girişimci olarak inovasyonda önemli bir rol oynamaktadır. Bu çerçevede, bilime, teknolojiye, inovasyona ve Ar - Ge'ye kaynak ayıran ülkelerin, sosyal ve ekonomik refah ve küresel rekabet açısından lider konumda oldukları görülmektedir (Public-University-Industry Cooperation, 2018).

Üniversite-sanayi işbirliği, bilginin ve teknolojinin aktarımıyla ilişkili olduğundan, bu işbirliği, şirketlerin ve dolayısı ile ekonomilerin daha rekabetçi hale gelmelerine yardımcı olan son derece önemli bir çalışma alanıdır. Ar - Ge yatırımlarının etkinliği, bilimsel ve teknolojik sistemdeki yerel şirketler ve kurumlar arasındaki etkileşimlere bağlıdır. Sanayileşmiş ülkelerin ekonomileri ve inovasyon seviyeleri incelendiğinde üretilen bilginin sanayide doğrudan kullanıldığ ve böylece küresel pazarlarda rekabetçi avantajlar elde ettikleri görülmektedir (Mascarenhas, Ferreira ve Marques, 2018). Üniversiteler ve endüstriler arasındaki işbirliği, bilgi transferini kolaylaştırabilir ve yeni bilgi ve teknolojinin üretimini teşvik edebilir (Leydesdorff ve Meyer, 2006; Enkel, Gassmann ve Chesbrough, 2009; Freitas ve Rossi, 2013).

Üniversiteler ve endüstri arasındaki işbirliği, hali hazırda küresel anlamda ilgi odağındadır. Hükümetler, üniversiteler ve endüstri, tüm taraflar için faydalı olacak iyi ve etkili işbirliği ile ilgilenmektedir. Üniversite-sanayi işbirliği, bilgi ve teknolojinin aktarımıyla ilişkili olduğundan bu işbirliği, şirketlerin ekonomileri daha rekabetçi hale getirmelerine yardımcı olan son derece önemli bir çalışma alanıdır (Mascarenhas vd., 2018). Üniversite sanayi işbirliğini ve dolayısıyla bu iki taraf arasındaki bilgi ve teknoloji 
transferini teşvik etmek için akademisyenler, politikacılar ve şirketler bilim ve teknoloji politikalarına her zamankinden daha fazla dikkat etmektedirler (Seppo ve Lilles, 2012).

\section{Küresel İnovasyon Endeksi}

İnovasyon kapasitesi, bir organizasyonun rekabet avantajına sahip olması için en önemli kavramlardan biridir. İnovasyon-yenilik-yenileşim kavramı sosyal ve ekonomik iyileşmeye değer katan yenilik şeklinde yapılabilir. İnovasyon işgücü ve toplam faktör verimliliği üzerine katkıda bulunarak, ülkelerin verimliliğini ve rekabet gücünü artırmakta ve böylece ekonomik büyümeye katkıda bulunmaktadır. Aynı zamanda istihdam kapasitesini pozitif yönde etkileyen inovasyon bir ülkenin refah düzeyine katkıda bulunmaktadır (Küresel Rekabet Endeksi Değerlendirmesi, 2017).

Küresel İnovasyon Endeksi (KİE) ülkelerin inovasyon ile ilgili politikaları ve uygulamaları aracilı̆ııla güçlü ve zayıf yönlerini açıç̧a ortaya koymaya yönelik tasarlanmıştır (Küresel İnovasyon Endeksi, 2017). Küresel İnovasyon Endeksi ülkelerin inovatif araştırmalar için ayırdıkları kaynakları detaylı bir şekilde incelemektedir. Dünya Fikri Haklar Örgütü (WIPO), Cornell Üniversitesi ve INSEAD işbirliği ile hazırlanan rapor, inovasyon ile ekonomik kalkınma arasındaki ilişkiye dikkat çekerek bu denklemde inovasyonu, ekonominin itici gücü olarak tanımlamaktadır.

Küresel İnovasyon Endeksi ülkelerin inovasyon kapasitelerini belirlerken inovasyon girdileri ve inovasyon çlktılar olmak üzere iki kategori oluşturmaktadır. İnovasyon girdileri ülke ekonomisinde inovasyon faaliyetlerinin temel bileşenleri olan kurumlar, insan kaynağı, altyapı, piyasa ve iş dünyasının gelişmişliğinden oluşurken inovasyon çıtılları ise bu girdiler tarafindan üretilen makale ve patent sayısı gibi bilişsel ve teknolojik ürünlerle temsil edilmektedir (INSEAD, 2007).

\section{Literatür Özeti}

Doanh Le, Phuong Thao Pham ve Bach Le (2019) çalışmalarında 2000 - 2015 dönemi için 25 Asya ülkesi verisini kullanarak inovasyon ve finansal gelişmişlik arasındaki ilişkiyi incelemişlerdir. Çalışmada inovasyon aktivitelerini temsilen patent başvurusu sayısı kullanılmıştır. Finansal piyasalar ise bankacılık sektörü ve hisse senedi piyasaları ayrımında incelenmiştir. Elde edilen bulgulara göre bankacllık sektörünün ve hisse senedi piyasalarının gelişimi patent başvurusu sayısını artırmaktadır. Fakat finansal yapı ile hesaplanan bankacılık sektörünün ve hisse senedi piyasalarının etkileşimi inovasyonla ilişkili değildir.

Zhang ve Matthews (2019) çalş̧malarında 1994 - 2016 döneminde ASEAN ülkelerinin ekonomik bütünleşmelerini, bankacılık sektörü rekabetçiliğinin gelişim ve yakınsama özelliklerini araştırarak incelemişlerdir. Çalışmada tekelci rekabet pazar yapısına doğru bir yakınsama olduğu bulgularına ulaşılmışır. Asya banka sektörü küresel çevreye karşı oldukça hassas ve küresel çevreden yoğun bir şekilde etkilenmektedir. Asya finansal krizi ve küresel finansal kriz dönemlerinde rekabetçilik zayıflamış, yakınsama yavaşlamışıtı fakat finansal bütünleşme politikası genel olarak ılımlı seviyede başarılıdır.

Tan, Wang, Yang ve Chang (2019) çalışmalarında, 2009 - 2016 dönemine ait 127 ülkenin verilerini kullanarak finansal rekabetçilik ve finansal açıklığın doğrudan yabancı sermaye yatırımları üzerindeki etkilerini incelemişlerdir. Elde edilen bulgulara göre finansal rekabetçilik ve finansal açıklı̆ı̆n gelişimi ülkelere gelen doğrudan yabancı sermaye yatırımlarını artırmaktadır. Ayrıca finansal rekabetçilik ve finansal açıklık bazı gelişmiş ülkelerin doğrudan yabancı sermaye açısından neden kötü durumda olduğunu açıklamakta önemli faktörlerdir.

Ayaydin, Çam, Barut ve Pala (2018) çalışmalarında BRICS - TM ülkelerinin 2000 - 2015 verilerini kullanarak ar - ge ve inovasyonun finansal gelişme üzerindeki etkisini araştırmışlardır. Çalışmada değişkenler arasında eşbütünleşme ilişkisi olduğu tespit edilmiştir. Uzun dönem denklem katsayılarına göre; ar - ge ve inovasyon yatırımları finansal gelişmeyi olumlu etkilemektedir. Ayrıca ar - ge yatırımlarından finansal gelişmeye doğru tek yönlü nedensellik ilişkisi olduğu belirlenmiştir.

Corbae ve Levine (2018) ABD bankacılık verilerini kullandıkları çalışmalarında rekabetin, istikrar; rekabetin risk etkisinin, etkinlik ve banka rekabetçiliğinin, para politikalarının etkinliği üzerindeki etkilerini araştırmışlardır. Rekabetin artması bankaların etkinlik ve kııılganlığını artırmaktadır. Ekonomiler banka denetimine yoğunlaşarak ve kaldıraç gereksinimlerini azaltarak rekabetin kırılganlık etkisinden kurtulabilirler. Rekabetçi koşullarda bankaların borç verme koşulları, merkez bankalarının dâhil olduğu faiz oranları değişikliklerine karşı fazla tepki verdiğinden para arz mekanizması bankaların rekabeti tarafından şekillenmektedir. 
Öztürk ve Göçmen Yağcılar (2018) çalışmalarında 2004 - 2016 dönemi BİST verilerini kullanarak inovasyon etkinliği ve finansal kısıtllılk arasındaki ilişkiyi incelemişlerdir. Elde edilen bulgulara göre finansal kısttlılık ile inovasyon etkinliği arasında ters yönlü ilişki bulunmaktadır. Finansal kısıtllık inovasyon etkinliğini olumsuz etkilemektedir. Ayrıca borç oranının artması da inovasyon etkinliğini azaltmaktadır. Diğer değişkenlerin tersine firma yaşının ve piyasa değerinin defter değerine oranının artması inovasyon etkinliğini olumlu etkilemektedir.

Kayalvizhi ve Thenmozhi (2018) çalışmalarında 1996 - 2005 dönemi verileriyle 22 gelişmekte olan ekonomi için teknoloji, kültür ve kurumsal yönetimin gelen doğrudan yabancı sermaye yatırımlarını nasıl etkilediğini araştırmışlardır. Elde edilen bulgulara göre gelen doğrudan yabancı sermaye yatırımlarını etkileyen en önemli faktör teknolojidir. Teknoloji ve inovasyon kapasitesindeki artışlar doğrudan yabanc1 sermaye yatırımlarını artırmaktadır. Kurumsal yönetim seviyesi artıkça doğrudan yabancı sermayeye olan etkisi de artmaktadır. Kültürel faktörler de doğrudan yabancı sermaye yatırımlarını etkilemektedir.

Sathappan (2018) çalışmasında yüksek eğitim ve endüstri arasındaki işbirliği olanaklarını araştırmıştır. Çalışmada üniversite dekanları, okul yöneticileri, şirket yöneticileri ve yönetim kurulu başkanlarıyla yapılan görüşmelerden elde edilen veriler kullanılmıştır. Üniversite - sanayi işbirliği öğrenciler açısından önemlidir. Çünkü işbirliği sayesinde üniversiteler öğrencilere yüksek kalitede eğitim verebilecek ve öğrenciler iş hayatının içerisinde yer alabileceklerdir. İşbirliği sayesinde Malezya'nın ekonomik gelişimine katkı sağlayacak bilgili ve yetenekli çalışanlar ortaya çıkacaktır. Üniversiteler daha yenilikçi, işletmeler ise verimlilik sayesinde daha kârlı hale gelecektir. Fakat işbirliği çabaları çoğunlukla üniversiteler tarafindan gösterilmektedir. Isşletmelerin ar - ge departmanlarında üniversitelerin aktif rol almaları desteklenerek üniversitenin bilgi birikimi yenilikçiliği geliştirmekte kullanılmalıdır.

Solovjova, Rupeika-Apoga ve Romānova (2018) çalışmalarında Riga Uluslararası Finans Merkezi’nin rekabetçilik artış yönünü, uluslararası finansal merkezlerin kuruluşunu etkileyen faktörlerin incelenmesi temelinde analiz etmişlerdir. Elde edilen bulgulara göre; uluslararası finansal merkezlerin gelişim ve rekabetçiliği; bankacillk sisteminin gelişimine, menkul kıymetler borsasının gelişimine, güvenli bankacılık sistemine ve yürürlükteki yasalara bağlıdır. Bankacılık endüstrisinin ve finansal kaynakların tekrar dağıtılmasının önemi göz ardı edilmemelidir. Riga, bir finansal merkez olarak rekabetçiliğini özel hizmetlere odaklanarak artırabilir.

Çıtak ve İltaş (2017) “Ar - Ge Yatırımlarının Finansal Performans Üzerindeki Etkisi ve BİST Teknoloji Endeksi Firmalarının Etkinliklerinin Değerlendirilmesi” isimli çalışmalarında Borsa İstanbul Teknoloji Endeksi'nde yer alan firmaların Ar - Ge yatırımlarının etkinliklerini 2013, 2014 ve 2015 yıllarına ait verileri kullanarak analiz etmiş̧ir. Analiz yöntemi olarak VZA kullanılmıştır. Ar - Ge Yoğunluğu ve Ar - Ge /Aktifler değişkenleri girdi, Aktif Karlılık Oranı ve PD/DD Oranı değişkenleri çıktı olarak kullanılmıştır. Çalışmada ele alınan firmaların saf teknik etkinlik düzeylerinin göreli olarak yüksek olduğu ve 2015’te beş firmanın tam saf teknik etkinliğe sahip olduğu sonucuna ulaşmışlardır.

Topaloğlu, Erkol ve Karakozak, 2017 yllında yaptıkları çalışmalarında BIST teknoloji sektöründe faaliyet gösteren firmaların $\mathrm{Ar}$ - Ge yatırımlarının hisse senedi getirilerine ve hisse senedi fiyat volatilitesine etkisini 2011-2015 yılları arasını panel regresyon yöntemi ile incelemişlerdir. Çalışma kapsamında $\mathrm{Ar}-\mathrm{Ge}$ yatırımları ve $\mathrm{Ar}-\mathrm{Ge}$ yoğunluğunun pay senedi getirilerine etkisinin incelendiği, $\mathrm{Ar}$ - Ge yatırımları ve Ar - Ge yoğunluğunun fiyat volatilitesine etkisi incelendiği iki model kurmuşlardır. Sonuç olarak BIST Teknoloji Bilişim sektöründe faaliyet gösteren firmalar için $\mathrm{Ar}$ - Ge yatırımlarının, pay senedi getirileri ve pay senedi fiyat volatilitesini etkileyen önemli faktörlerden biri olduğu sonucuna ulaşmışlardır. Ar $-\mathrm{Ge}$ yatırımları ile pay senedi getirileri arasında pozitif ilişki tespit ederek Ar - Ge yatırımlarının hissedarlar tarafindan olumlu karşılandığını ve firma değerini pozitif yönde etkileyen projeler olarak değerlendirdiğini iddia etmektedirler.

Hancioğlu ve Türkoğlu (2017) "Değişen Rekabet Anlayışı ve Sürdürülebilirliğin İşletmeler Üzerindeki Etkileri BIST Sürdürülebilirlik Endeksi’ndeki İşletmelerin Etkinliğinin Araştırılması" isimli çalışmalarında BIST sürdürülebilirlik endeksinde yer alan 27 işletmenin 2013-2015 yıllarını kapsayan finansal verileri kullanılarak etkinliklerini veri zarflama analizi modellerinden Süper Aylak Tabanlı Model vasitasıyla analiz etmişlerdir. Kullandıkları yöntemle, incelenen işletmelerin hem finansal etkinliklerini bulmuş hem de etkinlik sıralaması yapmış ve etkin bulunan işletmelerin de sıralamasını elde etmişlerdir. Sonuç olarak veri zarflama analizi yönteminin işletmelerin etkinliklerinin değerlendirilmesinde anlamlı sonuçlar verdiği sonucuna ulaşmışlardır. 
Özcan, Ağırman ve Yılmaz, 2014 yılında yaptıkları çalışmada BIST’te işlem gören teknoloji ve bilişim firmalarının $\mathrm{Ar}$ - Ge yatırımlarının bu şirketlerin hisse senedi fiyatlarına etkisini, 2000-2013 dönemini kapsayan veri setine panel veri analizi uygulayarak incelemişlerdir. Sonuç olarak $\mathrm{Ar}-\mathrm{Ge}$ harcamalarından hisse senedi getirilerine herhangi bir nedensellik sonucuna ulaşamamış ancak hisse senedi getirilerinden Ar - Ge harcamalarına bir nedensellik olduğu sonucuna ulaşmışlardır. Uyguladıkları hata düzeltme modeli sonuçları ortaya çıkan kısa dönemli dengesizliklerin uzun dönemde giderildiğini ortaya koymuştur.

Nicholas (2008) “İnovasyon Hisse Senedi Piyasasında Hızlı Yükselişlere Neden Oluyor mu?” isimli çalışmasında borsada 1910 ve 1939 yılları arasında kurumsal patentli varlıkların değerlenmesini incelemiştir. Yatırımcıların teknolojik yeniliklere 1920'lerde 1910’lara göre daha fazla önem verdikleri sonucuna ulaşmıştır. 1920'lerin sonlarında inovasyon borsa endeksi için itici güç durumundayken büyük buhranın yaşanması ile birlikte bu ivme hız kesmiştir. 1930’lu yillarda ileri teknoloji kullanan firmaların daha az gelişmiş teknoloji kullanan firmalara göre avantajlı konumunun ortadan kalktığı sonucuna ulaşmıştır.

Aghion, Bloom, Blundell, Griffith, ve Howitt, 2005 yılında yaptıkları çalışmada pazarda ürün rekabeti ve inovasyon arasındaki ilişkiyi incelemişlerdir. Panel veri kullanıldıkları çalışmalarında 1973 ve 1994 yılları arası İngiltere'de faaliyet gösteren 311 firmaya ait veri kullanmışlardır. Geliştirdikleri modele göre rekabet geri kalmış firmaların (muhtemel rekabetçi ortamda diğer firmalarla rekabet eme gücünden yoksun firmalar) yeniklik yapmadaki cesaretini kırsa da birbiriyle sıkı bir yarışta olan firmaları yenilik yapmaya teşvik etmektedir. Rekabet - inovasyon iliş̧isine göre, U-şeklinin hem artan hem de azalan kesimlerine dağıtılan endüstrilerle, tersine çevrilmiş bir U şeklini aldığına dair kanıtlar elde etmişlerdir.

Nickell (1996) "Rekabet ve Firma Performansı" isimli çalısmasında İngiltere'de faaliyet gösteren 670 işletme üzerine analiz yapmıştır. Yaptı̆̆ çalışmada rekabetin firma performansını artıracağı beklentisinin doğruluğunu araştırmıştır. Araştırmada teorik olarak bu hipotezin doğru olduğuna dair kanıtlar bulunmasına rağmen bu kanıtların ezici çoğunlukta olmadığını iddia etmektedir. Ancak yaptığı çalışma sonucunda rekabetin firma performansını artıracağı beklentisini desteklediği sonucuna ulaşmıştır.

Grosfeld ve Tressel, 2002 yılında yaptıkları çalısmalarında rekabet ve mülkiyet yapısının firma performansına etkisini analiz etmişlerdir. 1991-1998 yılları arası Varşova Menkul Kıymetler Borsası'nda faaliyet gösteren 200 finansal olmayan firmanın verileri ile yaptıkları çalışma sonucunda rekabetin performans üzerine olumlu ve anlamlı bir etkiye sahip olduğu sonucuna ulaşmışlardır.

\section{Yöntem}

Rekabetçilik ve yenilikçilik kavramlarını günümüzde önem kazanan kavramlardır. Ülkelerin rekabetçilik ve yenilikçilik özelliklerinin, ülkelerin ekonomik göstergeleri üzerinde önemli etkileri bulunmaktadır. $\mathrm{Bu}$ bağlamda ülkelerin önemli ekonomik göstergelerinden biri de şüphesiz finansal piyasalarıdır. Literatür incelendiğinde rekabetçiliğin farklı boyutlarıyla ilgili pek çok çalışma olduğu görülmektedir. Türkmen ve Aynaoğlu (2017) küresel rekabet endeksi ve küresel inovasyon endeksi arasındaki ilişkiyi; Zhang ve Matthews (2019) bankacilık bağlamında rekabetçiliği; Corbae ve Levine (2018) finansal piyasalardaki rekabetçiliği; Solovjova vd. (2018) uluslararası finansal merkezlerin rekabetçiliğe olan etkilerini; Tan vd. (2019) finansal rekabetçilik ve finansal açıklğın doğrudan yabancı sermaye yatırımları üzerindeki etkilerini incelemişlerdir. Bu çalışmalar incelendiğinde, çalışmalarda finansal kavramlar ve rekabetçilik her ne kadar birlikte yer alsa da bu çalışmalarda rekabetçiliğin, finansal piyasalar üzerindeki etkilerinin araştırmadığı görülmektedir. $\mathrm{Bu}$ çalışma bu yönüyle literatürdeki diğer çalışmalardan farklılaşmaktadır.

Literatürde ekonomik göstergeler, finansal piyasa göstergeleri ve inovasyon arasındaki ilişkiyi inceleyen pek çok çalışma bulunmaktadır (Pradhan vd., 2018; Öztürk ve Göçmen Yağcllar, 2018; Andriosopoulos, Faff, ve Paudyal, 2019 vb.). Bazı çalışmalarda ise inovasyonun yanında ar- ge yatırımlarının finansal gelişmişlik üzerindeki etkisi araştırılmışır (Ayaydin vd., 2018). İnovasyon, yeni bilgilerin dağıtılması ve ekonominin içine dâhil edilmesiyle sorumlu ulusal inovasyon sisteminin çeşitli bileşenlerinin etkileşimiyle üretilmektedir (Metcalfe, 1994). Bu bileşenlerden biri de üniversitelerdir. Günümüzde üniversiteler bilginin üretilmesinin yanında kullanılması konusunda da önemli görevler üstlenmektedir. Çok az firma ürettiği ürüne yenilik katacak teknolojik donanıma sahiptir (Miynat ve Gülden, 2016). Bu açıdan üniversiteler yenilik - yenilikçilik - inovasyon gibi kavramlarla yakından ilişkilidir. Üniversitelerle işbirliği içerisinde üretilen ürünlerin sağladığı katma değer ülke ekonomilerine olumlu katkılar sağlamaktadır. Bu nedenle bu çalışmada inovasyon kapasitesinin yanında araştırma 
geliştirme faaliyetlerinde üniversite sanayi işbirliği endeksi de kullanılmıştır. Burada amaç inovasyon gibi genel bir kavramı temsil eden inovasyon kapasitesi endeksi ile üniversite - sanayi işbirliği gibi daha spesifik bir kavramı temsil eden araştırma geliştirme faaliyetlerinde üniversite sanayi işbirliği endeksinin finansal piyasalar üzerindeki etkisini karşılaştırmaktır. İlgili literatür incelendiğinde daha önce üniversite - sanayi işbirliğinin finansal piyasalar üzerindeki etkilerinin bu şekilde ortaya konulmadığı görülmüştür. Çalışma bu yönüyle benzer çalısmalardan ayrilmaktadır. Ülkenin ekonomik büyüklüğü ile finansal piyasalarıyla ilgili göstergeler doğrudan ilişkili olduğundan çalışmada kontrol değişkeni olarak bu değiş̧kenlere ilaveten kişi başına gayrisafi yurtiçi hâsıla değişkeni de olarak kullanılmışır.

Çalışmada G20 ülkelerine ait 2007 - 2017 yılları arası veriler kullanılmıştır. Veriler Dünya Bankası veri tabanından ve www.investing.com adresinden elde edilmiştir. Çalışmada borsa endeksi (BE), rekabet endeksi (RE) ve rekabet endeksini oluşturan alt değişkenlerden inovasyon kapasitesi endeksi (IKE), kişi başına gayrisafi yurtiçi hâsıla (GSYH) ve araştırma geliştirme faaliyetlerinde üniversite sanayi işbirliğ̣i endeksi (ÜSİE) değişkenleri kullanılmıştır. Çalsşma iki aşamada gerçekleştirilmiştir. Öncelikle BE ile RE arasındaki ilişki ve daha sonra BE ile İKE, GSYH ve ÜsỉE değişkenleri arasındaki ilişki araştırılmıştır. Ele alınan ilişkiler en genel haliyle aşağıdaki modeller ile gösterilebilir:

$$
\begin{gathered}
B E=\alpha_{i t}+\beta_{i t} R E+u_{i t} i=1,2, \ldots, N ; t=1,2, \ldots, T \\
B E=\alpha_{i t}+\beta_{1 i t} \dot{I} K E+\beta_{1 i t} G S Y H+\beta_{3 i t} \mathrm{U} S \dot{I} E+u_{i t} i=1,2, \ldots, N ; t=1,2, \ldots, T
\end{gathered}
$$

Burada $\alpha_{i t}$, sabit terim, $\beta_{i t}, \beta_{1 i t}, \beta_{1 i t}$ ve $\beta_{3 i t}$ eğim parametreleri, $u_{i t}$ rassal hata terimi, $N$ yatay kesit birim sayısını ve $T$ dönem sayısıdır. Çalışmada kullanılan değişken katsayılarının karşılaştırılabilmesi için ölçüm birimlerinin aynı olması veya birimden arındırılmak için standartlaştırılması gerekmektedir. Ele alınan değişkenlerin ölçüm birimleri farklı olduğundan değişkenler standartlaştırılmıştır. Bu işlem sonucunda standartlaştırılan değişkenlerin ortalaması sıfır, varyans ve standart hataları ise bir olmaktadır. Standartlaştırma işlemi için $x_{i t}$, herhangi bir değişken, $x_{i t}^{*}$, bu değişkenin standartlaştırllmış hali, $\bar{x}$, bu değişkene ait ortalama ve $s s\left(x_{i t}\right)$, bu değisskene ait standart sapma olmak üzere aşağıdaki formül kullanılmıştır:

$$
x_{i t}^{*}=\frac{x_{i t}-\bar{x}}{s s\left(x_{i t}\right)}
$$

Kullanılan veri seti farklı birimler ve farklı dönemlere ait olduğundan bir panel veri setidir. Panel veri yatay kesit ve zaman boyutlarının her ikisini de içermektedir. Dolayısıyla daha fazla gözlem kullanılarak ekonometrik açıdan daha doyurucu tahminler elde edilmesine olanak sağlanmaktadır. Bunun yanında uygun tahmin ve test yöntemleri belirlenirken her iki boyuta ait özelliklerin de incelenmesi gerekmektedir. Bu bölümde kullanılan tahmin ve test yöntemler kısaca tanıtılacak ve sonuçlar sunularak yorumlanacaktır.

\section{Bulgular}

\section{Yatay Kesit Bağımlılık}

Panel veri analizlerinde kullanılan pek çok yöntem yatay kesit bağımlılık olmadığını varsayar. Bu özellikle çok ülkeden oluşan bir panel veri seti için sınırlayıcı bir varsayımdır. Yatay kesit bağımlılık olmasına rağmen, yatay kesit bağımlılık olmadığını varsayan yöntemlerin kullanılması hatalı tahmin ve test istatistiklerinin elde edilmesine yol açar. Bu nedenle uygun tahmin ve test yöntemleri belirlenirken yatay kesit bağımllık varsayımının geçerliliğ̣i test edilmelidir. Özellikle veriler rassal bir örnekleme süreciyle elde edilmemişse, spesifik bir anakütleden oluşuyorsa yatay kesit bağımlılık olup olmadığı araştırılmalıdır.

Panel veri modelinde farklı birimlere ait hata terimlerinin korelasyonlu olması yatay kesit bağımlılık olarak adlandirılır.

$$
y_{i t}=\beta_{0 i t}+\beta_{i t} X_{i t}+u_{i t}, \quad i=1,2, \ldots, N \text { ve } t=1,2, \ldots, T
$$

şeklindeki standart panel veri modeli gösteriminde, u hata terimi olmak üzere $i \neq j$ iken:

$$
\rho_{i j}=\operatorname{kor}\left(u_{i t}, u_{j t}\right)
$$

şeklinde ifade edilen korelasyon katsayısı $\rho_{i j}$ 'nin sıfırdan farklı olması yatay kesit bağımlılık olarak adlandırılır. Yatay kesit bağımlılık araştırılırken sıklıkla kullanılan testlerden biri de Pesaran (2004) yatay kesit bağımlılık testidir. Bu test uygulanırken aşağıdaki test istatistiği kullanılır: 


$$
\hat{\rho}_{i j}=\frac{\sum_{t=1}^{T} \widehat{u}_{i t} \widehat{u}_{j t}}{\sqrt{\sum_{t=1}^{T} \widehat{u}_{i t}^{2}} \sqrt{\sum_{t=1}^{T} \widehat{u}_{j t}^{2}}}
$$

olmak üzere;

$$
C D=\sqrt{\frac{2 T}{N(N-1)}}\left(\sum_{i=1}^{N-1} \sum_{j=i+1}^{N} \hat{\rho}_{i j}\right)
$$

biçimindedir. Yatay kesit bağımlılı̆̆ın olmadığı biçimindeki boş hipotez geçerliyken $N \rightarrow \infty$ ve $T$ yeterince büyük ise $C D \sim N(0,1)$ 'dir (Pesaran, 2004). Çalışmada kullanılan değişkenler için elde edilen test sonuçları aşağıdaki tabloda verilmiştir:

Tablo 1. Pesaran (2004) Yatay Kesit Bağmllhk Testi Sonuçlar

\begin{tabular}{lcccc}
\hline Değişken & CD-test & p değeri & kor & $\mid$ kor $\mid$ \\
\hline BE & 23,190 & 0,000 & 0,561 & 0,590 \\
RE & 5,620 & 0,000 & 0,136 & 0,458 \\
IKE & 12,460 & 0,000 & 0,301 & 0,551 \\
ÜSİE & 11,790 & 0,000 & 0,285 & 0,480 \\
GSYH & 15,790 & 0,000 & 0,382 & 0,510 \\
\hline
\end{tabular}

Elde edilen $\mathrm{p}$ değerlerine göre \%5 önem seviyesinde yatay kesit bağımlılı̆̆ın olmadığı biçimindeki boş hipotez reddedilir. Yani seriler yatay kesit bağımlılık içermektedir. Bu nedenle yapılacak testlerde ve tahmin edilecek modellerde yatay kesit bağımlılık dikkate alınmalıdır.

\section{Durağanlık}

Panel veri analizlerinde ve zaman serileri analizlerinde araştırılması gereken önemli bir varsayım durağanlıktır. Herhangi bir serinin beklenen değer, varyans ve kovaryansının zamana göre değiş̧memesi durağanlı̆̆ ifade eder. Kullanılan serilerin durağan olmaması durumunda hatalı test istatistikleri elde edilebilmekte ve sahte regresyon problemi ortaya çıkabilmektedir. Sahte regresyon gerçekte olmayan bir ilişkiyi yansıtır. Sahte regresyon durumumda ilişkisiz değişkenler için istatistiki olarak anlamlı regresyon modelleri elde edilir.

Panel veri analizlerinde kullanılan bazı testler yatay kesit bağımlılığ dikkate alırken bazı testler ise yatay kesit birimlerin bağımsız olduğunu varsaymaktır. Pesaran (2004) testi sonuçları çalışmada kullanılan birimlerin yatay kesit bağımlılık içerdiğini göstermektedir. Pesaran (2004) tarafından geliştirilen test, yatay kesit bağımlılık durumunda kullanılabilmektedir. Bu testte birim kök testlerini tahmin edilen faktörlerden sapmalar üzerine oturtmak yerine standart DF denklemleri, gecikmeli seviyelerin yatay kesit ortalamaları ve birimlere ait serilerin birinci farkları kullanılarak yatay kesit bağımlılığa duyarlı hale getirilmiştir (Pesaran, 2007).

$\mathrm{Bu}$ testte standart $A D F$ istatistiklerinin yatay kesit uyarlanmıs hali olan $C A D F$ istatistiklerinin her bir birim için hesaplanan $\left(C A D F_{i}\right)$ değerinin ortalaması (CIPS) kullanılmaktadır.

$$
C I P S=t-b a r=\frac{1}{N} \sum_{i=1}^{N} C A D F_{i}
$$

Alternatif olarak $p_{i t}$ i. yatay kesit birimin bireysel birim kök testi için elde edilen “ $p$ değeri" olmak üzere ters normal dağılım kullanılarak elde edilen $Z$ istatistiği kullanılabilir. $Z$ istatistiği aşağıdaki gibi hesaplanır:

$$
Z=\frac{1}{\sqrt{N}} \sum_{i=1}^{N} \Phi^{-1} p_{i T}
$$

$f_{t}$ gözlemlenemeyen genel etkiler ve $\varepsilon_{i t}$ birimlere özgü hata iken $y_{i t}$, aşağıdaki gibi basit dinamik lineer heterojen panel veri modeli yapısına sahip bir değişken olmak üzere:

$$
\begin{gathered}
y_{i t}=\left(1-\emptyset_{i}\right) \mu_{i}+\emptyset_{i} y_{i t-1}+u_{i t} \\
u_{i t}=\gamma_{i} f_{t}+\varepsilon_{i t}
\end{gathered}
$$


için $\alpha_{i}=\left(1-\emptyset_{i}\right) \mu_{i}$ ve $\beta_{i}=-\left(1-\emptyset_{i}\right)$ olmak üzere aşağıdaki fark denklem yazılabilir:

$$
\Delta y_{i t}=\alpha_{i}+\beta_{i} y_{i t-1}+\gamma_{i} f_{t}+\varepsilon_{i t}
$$

Bu denklem için tüm birimlerin birim kök $\left(\emptyset_{i}=1\right)$ içerdiği biçimindeki boş hipotez ve bazı birimler için durağanlığı ifade eden heterojen alternatif hipotez aşağıdaki gibidir (Pesaran, 2007):

$$
\begin{aligned}
& H_{0}: \beta_{i}=0, i=1,2, \ldots, N \\
& H_{1}: \beta_{i}<0, \quad i=1,2, \ldots, N_{1}, \quad \beta_{i}=0, i=N_{1}+1, N_{1}+2, \ldots, N
\end{aligned}
$$

Çalışmada kullanılan değişkenler için elde edilen test sonuçları aşağıdaki tabloda verilmiştir:

Tablo 2. Pesaran (2007) Panel Birim Kök Testi Sonuçar

\begin{tabular}{lcccccccc}
\hline \multirow{2}{*}{ Değişken } & \multicolumn{3}{c}{ Düzey } & \multicolumn{3}{c}{ Birinci Fark } \\
\cline { 2 - 9 } & \multicolumn{3}{c}{ Trendli } & \multicolumn{2}{c}{ Trendsiz } & \multicolumn{2}{c}{ Trendli } & \multicolumn{2}{c}{ Trendsiz } \\
\cline { 2 - 9 } & Zt-bar & p değeri & Zt-bar & p değeri & Zt-bar & p değeri & Zt-bar & p değeri \\
\hline BE & 1,639 & $\mathbf{0 , 9 4 9}$ & $-0,236$ & 0,407 & $-0,781$ & 0,217 & $-2,595$ & $\mathbf{0 , 0 0 5}$ \\
RE & 0,418 & $\mathbf{0 , 6 6 2}$ & $-1,381$ & 0,084 & $-1,962$ & 0,025 & $-1,423$ & $\mathbf{0 , 0 7 7}$ \\
IKE & $-3,835$ & $\mathbf{0 , 0 0 0}$ & $-5,486$ & 0,000 & - & - & - & - \\
ÜSंE & $-2,812$ & $\mathbf{0 , 0 0 2}$ & $-2,073$ & 0,019 & - & - & - & - \\
GSYH & $-1,046$ & $\mathbf{0 , 1 4 8}$ & 1,029 & 0,848 & $-0,120$ & 0,452 & $-1,965$ & $\mathbf{0 , 0 2 5}$ \\
\hline
\end{tabular}

Seriler incelendiğinde düzey değerlerinin trend içerdiği, birinci fark değerlerinin ise fark alma işlemi sonucu trendsiz hale geldiği tespit edilmiştir. Bu nedenle durağanlık testinde düzey için trendli, birinci fark için trendsiz denklemlere ait istatistikler temel alınmıştır. Elde edilen $\mathrm{p}$ değerlerine göre $\% 5$ önem seviyesinde serilerin düzey değerleri için $\mathrm{BE}, \mathrm{RE}$ ve GSYH serilerinin birim kök içerdiği biçimindeki boş hipotez reddedilemez. BE ve GSYH serilerinin fark1 için \%5 önem seviyesinde, RE serisinin birinci fark1 için \%10 önem seviyesinde birim kök hipotezi reddedilir. BE, RE ve GSYH serileri birinci fark durağandır (I(1)). \%5 önem seviyesinde İKE ve ÜSİE serilerinin düzey değerleri için serilerin birim kök içerdiği biçimindeki boş hipotez reddedilir. İKE ve ÜsİE serileri seviyede durağandır (I(0)).

\section{Westerlund Panel Eşbütünleşme Testi}

Eşbütünleşme, fark durağan serilerin uzun dönemde ilişkili olmalarını ifade etmektedir. Durağan olmayan serilerin doğrusal bileşimleri durağansa seriler eşbütünleşiktir. Durağan olmayan seriler fark alınarak durağanlaştırllabilir. Fakat fark alma uzun dönem bilgiyi yok eder. Eşbütünleşme analizi uzun ve kısa dönem bilgiyi korumak amacıyla yapılır. Panel veri söz konusu olduğunda yatay kesit bağımlılık eşbütünleşme açısından da önemli bir husustur. Yatay kesit bağımlılık söz konusu olduğunda yapılacak eşbütünleşme testinde dikkate alınmalıdır. Pesaran (2004) testi sonuçlanı kullanılan serilerin yatay kesit bağımlılık içerdiğini göstermiştir. Bu nedenle yatay kesit bağımlılığı dikkate alan testler kullanılmalıdır. Westerlund Panel Eşbütünleşme Testi yatay kesit bağımlılığı dikkate alan testlerdendir. Yatay kesit bağımlılık durumunda dirençli kritik değerler kullanılmalıdır. Bu testin kullanılabilmesi için serilerin aynı seviyede durağan olması gerekmektedir. Bu test dört farklı test istatistiği kullanılarak yapılmaktadır ve boş hipotez "eşbütünleşme ilişkisi yoktur" biçimindedir (Westerlund, 2007). Test aşağıdaki denklem tahmin edilerek gerçekleştirilir:

$$
\Delta y_{i t}=\hat{\delta}_{i}^{\prime} d_{t}+\hat{\alpha}_{i} y_{i t-1}+\hat{\lambda}_{i}^{\prime} x_{i t-1}+\sum_{j=1}^{p_{i}} \hat{\alpha}_{i j} \Delta y_{i t-j}+\sum_{j=0}^{p_{i}} \hat{\gamma}_{i j} \Delta x_{i t-j}+\hat{e}_{i j}
$$

Test istatistikleri aşağıdaki gibi hesaplanır (Westerlund, 2007):

$$
\begin{gathered}
G_{\tau}=\frac{1}{N} \sum_{i=1}^{N} \frac{\hat{\alpha}_{i}}{S E\left(\hat{\alpha}_{i}\right)} \\
G_{\alpha}=\frac{1}{N} \sum_{i=1}^{N} \frac{T \hat{\alpha}_{i}}{\hat{\alpha}_{i}(1)} \\
P_{\tau}=\frac{\hat{\alpha}}{S E(\hat{\alpha})} \\
P_{\alpha}=T \hat{\alpha}
\end{gathered}
$$


Çalışmanın ilk aşamasında BE ile RE arasındaki eşbütünleşme ilişkisi test edilmiştir. Seriler aynı seviyede durağan olduğundan eşbütünleşme ilişkisi Westerlund Panel Eşbütünleşme Testi ile araştırılmıştır. $\mathrm{BE}$ ile RE değişkenleri arasındaki eşbütünleşme testi için test sonuçları aşağıdaki tabloda verilmiştir:

Tablo 3. Westerlund Panel Eşbütünleşme Testi Sonuclar

\begin{tabular}{cccc}
\hline İstatistik & Değer & p değeri & Dirençli p değeri \\
\hline$G_{\tau}$ & $-5,539$ & 0,000 & 0,203 \\
$G_{\alpha}$ & $-8,821$ & 0,096 & 0,345 \\
$P_{\tau}$ & $-14,047$ & 0,000 & 0,398 \\
$P_{\alpha}$ & $-8,672$ & 0,000 & 0,408 \\
\hline
\end{tabular}

Elde edilen tüm istatistiklerin dirençli p değerlerine göre \%5 önem seviyesinde "eșbütünleșme ilișkisi yoktur" biçimindeki boş hipotez reddedilemez. Seriler arasında eşbütünleşme yoktur, seriler uzun dönemde ilişkili değildir.

\section{Panel ARDL Modeli}

Çoğu yöntemde uzun dönemli ilişkilerin ve eşbütünleşme analizi için serilerin aynı seviyede durağan olduğu varsayımı yapılmaktadır. Bu varsayım geçerli olmamasına rağmen bu varsayımı gerektiren yöntemlerin kullanılması hatalı sonuçlar elde edilmesine yol açmaktadır. Ardışık bağımlı dağıtılmış gecikme (Autoregressive Distributed Lag -ARDL) modeli ise serilerin $\mathrm{I}(0)$ veya $\mathrm{I}(1)$ olmasını göz önünde bulundurmaksızın ve küçük örneklemler için uzun dönemli ilişkilerin analizinde kullanılabilmektedir (Pesaran ve Shin, 1998).

Durağanlık testi sonuçlarına göre BE ve GSYH'nın I(1), İKE ve ÜSİE’nin I(0) olduğu tespit edilmiştir. Değişkenlerin durağanllk seviyeleri birbirinden farklı olduğundan uzun dönem ilişkilerin analizinde Panel ARDL modeli kullanılmıştır. BE’nin bağımlı değişken, $\quad X_{i t}=$ $\left[G S Y H_{i t} \dot{\mathrm{I}} K E_{i t} \quad\right.$ ÜSİ $\left.E_{i t}\right]$ olmak üzere $X_{i t}$ 'nin açıklayıc1 değişken matrisi olduğu model Panel ARDL formatında aşağıdaki gibi yazılır:

$$
B E_{i t}=\mu_{i}+\sum_{j=1}^{p} \lambda_{i j} B E_{i t-j}+\sum_{j=0}^{q} \delta_{i j}^{\prime} X_{i t-j}+\varepsilon_{i t}
$$

Bu modelin tahmininde genel olarak ortalama grup (MG) tahmincisi ve havuzlanmış ortalama grup (PMG) tahmincisi olmak üzere iki yöntem kullanılmaktadır. PMG tahmincisinin kullanımı, MG tahmincisinin ortaya çıkarabileceği pek çok problemi ortadan kaldırdığından daha uygundur (Erdem, Güloğlu ve Nazlığlu, 2010). PMG uzun dönem katsayılarının tüm birimler için aynı olduğunu, kısa dönem katsayılarının, sabit terimin ve hata varyansının yatay kesit birimler arasında farklılaştı̆̆ını varsayar. Tüm değişkenler arasındaki uzun dönem denge ilişkisinin tüm birimler için aynı olduğunu varsaymak için bütçe ve ödeme gücü kısıtları, arbitraj koşulları veya genel teknolojilerin tüm birimleri benzer etkilemesi gibi makul nedenler bulunmaktadır (Pesaran, Shin ve Smith, 1999). Modelde parametrelerin ifadesi için aşağıdaki gösterim daha kullanışlıdır:

$$
\Delta B E_{i t}=\mu_{i}+\phi_{i} B E_{i t-1}+\beta_{i}^{\prime} X_{i t}+\sum_{j=1}^{p-1} \lambda_{i j}^{*} \Delta B E_{i t-j}+\sum_{j=0}^{q-1} \delta_{i j}^{* \prime} \Delta X_{i t-j}+\varepsilon_{i t}
$$

Burada $\phi_{i}=-\left(1-\sum_{j=1}^{p} \lambda_{i j}\right), \beta_{i}=\sum_{j=0}^{q} \delta_{i j}, j=1,2, \ldots, p$-1 olmak üzere $\lambda_{i j}^{*}=-\sum_{m=j+1}^{p} \lambda_{i m}$ ve $j=1,2, \ldots, q-1$ olmak üzere $\delta_{i j}^{*}=-\sum_{m=j+1}^{q} \delta_{i m}$ biçimindedir.

Modelde $\mu_{i}$, sabit terim, $\phi_{i}$, hata düzeltme terimi, $\beta_{i}^{\prime}$ uzun dönem katsayılar vektörü, $\delta_{i j}^{* \prime}$, k1sa dönem katsayllar vektörüdür. Negatif ve anlamlı $\phi_{i}$ hata düzeltme terimi hem eşbütünleşme hem de uzun dönem denge olduğunu göstermektedir (Erdem vd., 2010). Sıfir ile bir arasında ve negatif bir hata düzeltme terimi, dışsal şokların etkisinin hata düzeltme mekanizması ile ortadan kalktığını göstermektedir (Asongu, El Montasser ve Toumi, 2016). Bu model $\varepsilon_{i t}$ 'nin normal dağıldığı varsayımıyla en yüksek olabilirlik yöntemiyle tahmin edilir (Pesaran vd., 1999).

$\mathrm{Bu}$ aşamada öncelikle Wald testi yardımıyla $\beta_{i}^{\prime}=0$ yani "uzun dönem ilişki - eşbütünleşme yoktur" biçimindeki sınırlama test edilmiştir. Bu testte hipotezler ve test istatistikleri aşağıdaki gibidir: 


$$
\begin{aligned}
& H_{0}: \beta_{i}^{\prime}=0(\text { Eşbütünleşme }- \text { uzun dönem ilişki yoktur }) \\
& H_{1}: \beta_{i}^{\prime} \neq 0(\text { Eşbütünleşme - uzun dönem ilişki vardır })
\end{aligned}
$$

Tablo 4. Wald Testi Sonuclar

\begin{tabular}{ccc}
\hline Test İstatistiği & Değer & p değeri \\
\hline $\mathrm{F}$ & 612069,30 & 0,000 \\
$\chi^{2}$ & 1836208,00 & 0,000 \\
\hline
\end{tabular}

Her iki test istatistiğinin $\mathrm{p}$ değerine göre de boş hipotez reddedilir. Yani eşbütünleşme - uzun dönem ilişki vardır. ARDL $(1,1,1,1)$ modeli için PMG yöntemi tahminleri aşağıdaki gibidir:

Tablo 5. ARDL(1,1,1,1) Modeli İcin PMG Yöntemi Genel Katsayı Tabminleri

\begin{tabular}{lcccc}
\hline \multirow{2}{*}{ Değişken } & \multicolumn{4}{c}{ Uzun Dönem Denklemi } \\
\cline { 2 - 4 } & Katsayı & Std, Hata & t istatistiği & p değeri \\
\hline İKE & 0,063 & 0,0003 & 220,354 & 0,000 \\
ÜSİE & 0,107 & 0,001 & 132,103 & 0,000 \\
GSYH & 0,014 & 0,001 & 19,901 & 0,000 \\
\hline \multirow{2}{*}{ Değişken } & Katsayı & Kisa Dönem Denklemi & p değeri \\
\cline { 2 - 4 } & $-0,708$ & Std, Hata & t istatistiği & 0,000 \\
HDT & 0,119 & 0,154 & $-4,603$ & 0,357 \\
D(İKE) & $-0,116$ & 0,129 & 0,925 & 0,450 \\
D(ÜSİE) & 0,979 & 0,153 & $-0,759$ & 0,286 \\
D(GSYH) & 0,018 & 0,913 & 1,073 & 0,945 \\
C & 0,262 & 0,069 & \\
\hline
\end{tabular}

Tüm birimler için elde edilen genel sonuçlar yukarıdaki tabloda verilmiştir. Sonuçlara göre Hata Düzeltme Terimi (HDT), 0 ile -1 arasında bir değer almıştır ve anlamlıdır. Bu durum hata düzeltme mekanizmasının çalıștığını dışsal şokların etkisinin bir dönemde yaklaşık \%71'inin hata düzeltme mekanizması ile ortadan kalktığını göstermektedir. Değişkenler arasında uzun dönem dengesi bulunmaktadır. Uzun dönem katsayıların tamamı \%5 önem seviyesinde anlamlıdır. Tüm katsayılar pozitiftir. Yani uzun dönemde İKE, ÜSİE ve GSYH'daki artışlar BE'ni artırmaktadır. İKE'nde meydana gelecek bir standart birim değişim BE’ni aynı yönde 0,063 standart birim değiştirmektedir. ÜSİE’nde meydana gelecek bir standart birim değişim BE’ni aynı yönde 0,107 standart birim değiştirmektedir. GSYH'da meydana gelecek bir standart birim değişim BE'ni aynı yönde 0,014 standart birim değiştirmektedir. Değişkenler standartlaştırılarak tahminler yapıldığından, katsayı büyüklükleri, açılayıc1 değişkenlerin bağımlı değişken üzerindeki etkilerinin büyüklüklerini karşılaştırmada kullanılmasına olanak sağlamaktadır. Buna göre bu değişkenler arasında BE üzerinde etkisi en fazla olan değişken ÜSEİ endeksidir. Daha sonra etki büyüklüklerine göre İKE ve GSYH değişkenleri sıralanabilir. Kısa dönem katsayıların tamamı ise \%5 önem seviyesinde anlamsızdır.

Bilindiği gibi PMG uzun dönem katsayılarının tüm birimler için aynı olduğunu, kısa dönem katsayılarının ve sabit terimin yatay kesit birimler arasında farklılaştığını varsayar. Bu nedenle yukarıda sunulan kısa denklem tahminlerinin yanında her bir yatay kesit birim için ayrı kısa dönem denklem tahminleri elde edilir. Her bir ülke için elde edilen kısa dönem katsayı tahminleri ise tablo 6'da sunulmuştur.

Elde edilen sonuçlara göre Brezilya, Çin, Meksika ve İngiltere haricindeki ülkeler için hata düzeltme terimi anlamlı ve beklenilen aralıkta değerler almıştır. Bu ülkeler için hata düzeltme mekanizması işlemektedir. Arjantin, Kanada, Almanya, Hindistan, Sudi Arabistan, Türkiye ve ABD için İKE’ye ait katsayı pozitif ve anlamlıdır. Kısa dönemde bu ülkeler için IKKE'deki artışlar, BE'ni olumlu etkilemektedir. İKE, BE'ni en fazla Türkiye için etkilemektedir. Avustralya, Çin, Fransa, Endonezya, Japonya, Kore, Rusya ve İngiltere için İKE'ye ait katsayı negatif ve anlamlıdır. Kısa dönemde bu ülkeler için İKE'deki artışlar, BE'ni olumsuz etkilemektedir. Olumsuz etki en fazla Brezilya için görülmektedir. Arjantin, Çin, Almanya, Endonezya, İtalya ve Kore için ÜSİE’ye ait katsayı pozitif ve anlamlıdır. Kısa dönemde bu 
ülkeler için ÜSİE'deki artışlar, BE’ni olumlu etkilemektedir. Olumlu etki en fazla İtalya için görülmektedir. Avustralya, Kanada, Fransa, Hindistan, Rusya, Sudi Arabistan, Türkiye, İngiltere ve ABD için Üsi̇E’ye ait katsayı negatif ve anlamlıdır. Kısa dönemde bu ülkeler için ÜSİE'deki artışlar, BE'ni olumsuz etkilemektedir. Olumsuz etki en fazla Türkiye için görülmektedir. Kanada, Endonezya, Rusya, İngiltere ve ABD için GSYH'ya ait katsayı pozitif ve anlamlıdır. Kısa dönemde bu ülkeler için GSYH'daki artışlar, BE'ni olumlu etkilemektedir. Olumlu etki en fazla Endonezya için görülmektedir. Arjantin, Avustralya, Çin, Fransa, Almanya, İtalya, Japonya, Kore, Sudi Arabistan için GSYH'ya ait katsayı negatif ve anlamlıdır. Kısa dönemde bu ülkeler için GSYH'daki artışlar, BE'ni olumsuz etkilemektedir. Olumsuz etki en fazla Çin için görülmektedir.

Tablo 6. ARDL(1,1,1,1) Modeli İ̧in PMG Yöntemi Birim Kısa Dönem Katsayı Tahminleri

\begin{tabular}{|c|c|c|c|c|c|}
\hline Ülkeler & HDT & İKE & ÜSİE & GSYH & Sabit \\
\hline Arjantin & $0,374^{*}$ & $0,209 *$ & $0,046^{*}$ & $-0,560^{*}$ & $0,226^{*}$ \\
\hline Avustralya & $-0,756^{*}$ & $-0,005^{*}$ & $-0,036^{*}$ & $-0,056^{*}$ & $-0,528^{*}$ \\
\hline Brezilya & $-1,698^{*}$ & $-0,657$ & $-0,119$ & 4,699 & $3,640^{*}$ \\
\hline Kanada & $-1,695^{*}$ & $0,348^{*}$ & $-0,276^{*}$ & $0,055^{*}$ & $-0,542^{*}$ \\
\hline Çin & $-1,002^{*}$ & $-0,098^{*}$ & $0,008^{* *}$ & $-1,648^{*}$ & $-0,644^{*}$ \\
\hline Fransa & $-0,862^{*}$ & $-0,070^{*}$ & $-0,122^{*}$ & $-0,076^{*}$ & $-0,601 *$ \\
\hline Almanya & $-0,443 *$ & $0,621 *$ & $0,144^{* *}$ & $-0,112^{*}$ & $-0,265^{*}$ \\
\hline Hindistan & $-0,899^{*}$ & $0,669 *$ & $-0,295^{* *}$ & 16,512 & $0,236^{*}$ \\
\hline Endonezya & $-0,849 *$ & $-0,032 *$ & $0,029 *$ & $1,191 * *$ & $-0,511 *$ \\
\hline İtalya & $-0,689 *$ & 0,207 & $0,646^{* * *}$ & $-0,463^{*}$ & $0,069^{*}$ \\
\hline Japonya & $-0,259 *$ & $-0,628^{* *}$ & 0,059 & $-0,277^{*}$ & $-0,125^{*}$ \\
\hline Kore & $0,655^{*}$ & $-0,055^{*}$ & $0,043^{*}$ & $-0,184^{*}$ & $0,549 *$ \\
\hline Meksika & 0,169 & $-0,165$ & 0,472 & $-1,710$ & $-0,142$ \\
\hline Rusya & $-0,890^{*}$ & $-0,048^{*}$ & $-0,051 *$ & $0,014^{*}$ & $-0,528^{*}$ \\
\hline Sudi Arabistan & $-0,857^{*}$ & $0,023^{*}$ & $-0,095^{*}$ & $-0,135^{*}$ & $-0,373^{*}$ \\
\hline Güney Afrika & $-0,094$ & 0,271 & 0,544 & 0,159 & $0,119 * * *$ \\
\hline Türkiye & $-0,810^{*}$ & $1,922 * *$ & $-2,630 * * *$ & 0,780 & $2,156^{*}$ \\
\hline İngiltere & $-1,885^{*}$ & $-0,470^{*}$ & $-0,263 *$ & $0,200^{*}$ & $-1,419 *$ \\
\hline $\mathrm{ABD}$ & $-0,957^{*}$ & $0,222^{*}$ & $-0,309 *$ & $0,218^{*}$ & $-0,975^{*}$ \\
\hline
\end{tabular}

*, ** ve *** sirasıly \%1, \%5 ve \%10 önem seviyesinde anlamlılı̆̆ ifade etmektedir,

\section{Tartışma, Sonuç ve Öneriler}

Günümüzde yenilikçilik, rekabetçilik ve benzer kavramların ülke ekonomileri üzerindeki etkileri dikkat çeken araştırma konularıdır. Şüphesiz ki ülke ekonomisinin genel durumunu yansıtan önemli değişkenlerden biri de ülke borsa endeksidir. Çalışmada amaç ülkenin rekabet gücü ve yenilikçiliğinin borsa endeksi üzerindeki etkisinin araştırılmasıdır. Rekabet gücünü temsilen rekabet endeksi, yenilikçiliği temsilen ise inovasyon kapasitesi endeksi, ar - ge faaliyetlerinde üniversite sanayi işbirliği endeksi kullanılmıştır. Ayrıca ülke ekonomisinin büyüklüğünün borsa endeksi üzerindeki etkisini üstlenmesi açısından kişi başına gayrisafi yurtiçi hâsıla değişkeni de modelin bağımsız değisskenleri arasına dâhil edilmiştir.

Rekabet edebilirlik, bir ülke ekonomisinin serbest ticaret ve piyasa koşulları altında, ulusal ve uluslararası piyasaların taleplerini karşılayan mal ve hizmetleri üretebilme gücüne hangi ölçüde sahip olduğunu açıklayan bir kavramdır. Bu açıdan rekabet edebilirliğin, ülke ekonomisin genel durumunu yansitan makroekonomik faktörler üzerinde etkili olması beklenmektedir. Ancak çalışmada elde edilen analiz bulguları rekabet edebilirlik ile borsa endeksi arasında uzun dönemli ilişkinin olmadığını göstermektedir.

Borsa endeksi ile inovasyon kapasitesi endeksi, Ar - Ge faaliyetlerinde üniversite sanayi işbirliği endeksi ve kişi başına gayrisafi yurtiçi hâsıla değişkenleri arasında uzun ve kısa dönemde ilişki bulunmaktadır. Ele alınan faktörlerden borsa endeksini en fazla etkileyen faktör, üniversite sanayi 
işbirliğidir. Analiz sonuçları dışsal şokların yani olağandışı durumların etkisinin, bir dönemde yaklaşık \%71'inin hata düzeltme mekanizması ile ortadan kalktı̆̆ını göstermektedir.

Üniversiteler eğitim kurumları olmalarının yanı sıra yapılan bilimsel yeniliklerin sanayide kullanması sonucunda ülke ekonomilerine olumlu katkılar sağlamaktadır. Çalışmada elde edilen sonuçlar, uzun dönemde üniversite sanayi işbirliği arttı̆̆ında borsa endeksinin de arttı̆̆ını göstermektedir. Bu sonuç beklentileri destekleyici niteliktedir. Üniversitede yapilan bilimin topluma yansitılmasının ve sanayide kullanılmasının ülke ekonomisi üzerinde olumlu etkileri bulunmaktadır. Gelişmiş ve gelişmekte olan ülkeler, üniversiteleri sadece eğitim kurumu olmaktan çıkarıp sanayi ile işbirliği sayesinde, ülke ekonomisine katkı sağlayan birimler haline getirmişlerdir. Ülke ekonomisini gelişimi üniversite - sanayi işbirliğinin arttırlmasıyla sağlanabilir. Kısa dönemde üniversite sanayi işbirliği, borsa endeksini bazı ülkeler için olumlu bazı ülkeler için ise olumsuz etkilemektedir. Olumlu etki en fazla İtalya'da, olumsuz etki en fazla ABD'de görülmektedir.

İnovasyon, yenilik/yenileşim anlamlarında kullanılmaktadır. İnovasyon işgücü ve toplam faktör verimliliği üzerine katkıda bulunarak, ülkelerin verimliliğini ve rekabet gücünü artırmakta ve böylece ekonomik büyümeye katkıda bulunmaktadır. Elde edilen sonuçlar, beklentiler paralelinde uzun dönemde inovasyon kapasitesi arttığında borsa endeksinin de arttığını göstermektedir. Yenilikçilik borsa endeksini olumlu etkilemektedir. Yenilikçilik ülkelere diğer ülkeler karşısında avantaj sağlamaktadır. İnovasyon kapasitesi endeksi, kısa dönemde borsa endeksini bazı ülkeler için olumlu, bazı ülkeler için ise olumsuz etkilemektedir. En fazla olumlu etkinin Türkiye, en fazla olumsuz etkinin ise Brezilya için elde edildiği görülmektedir.

Kişi başına gayrisafi yurtiçi hâsıla ülkelerin ekonomik gücünü, birikimini gösteren bir faktördür. Uzun dönemde kişi başına gayrisafi yurtiçi hâsıla, borsa endeksini olumlu etkilemektedir. Güçlü ekonomilerin borsası da güçlüdür. Kısa dönemde ise diğer değişkenlerde de olduğu gibi aynı yönlü ve ters yönlü ilişkinin tespit edildiği ülkeler bulunmaktadır. Olumlu etki en fazla Endonezya'da, olumsuz etki ise en fazla Çin'de görülmektedir.

\section{Etik Beyan}

“Finansal Piyasalar, Rekabetçilik, İnovasyon ve Üniversite-Sanayi İşbirliği: G20 Örneği” başlıklı çalışmanın yazım sürecinde bilimsel, etik ve alıntı kurallarına uyulmuş; toplanan veriler üzerinde herhangi bir tahrifat yapılmamış ve bu çalşsma herhangi başka bir akademik yayın ortamına değerlendirme için gönderilmemiştir.

\section{Kaynakça}

Aghion, P., Bloom, N., Blundell, R., Griffith, R. ve Howitt, P. (2005). Competition and innovation: An inverted-U relationship. The Quarterly Journal of Economics, 120(2), 701-728.

Andriosopoulos, D., Faff, R. ve Paudyal, K. (2019). Financial markets, innovation and regulation. The European Journal of Finance, 25(7), 595-598. doi:10.1080/1351847X.2019.1571727

Asongu, S., El Montasser, G. ve Toumi, H. (2016). Testing the relationships between energy consumption, CO2 emissions, and economic growth in 24 african countries: A panel ARDL approach. Environmental Science and Pollution Research, 23(7), 6563-6573.

Ayaydin, H., Çam, A. V., Barut, A. K. ve Pala, F. (2018). Araştırma geliştirme ve inovasyon yatırımlarının finansal gelişme üzerine etkisi: BRICS-TM ülkeleri örneği. Muhasebe ve Vergi Uygulamalar Dergisi(2018 Special Issue), 442461.

Mascarenhas, C., Ferreira, J J. ve Marques, C. (2018). University-Industry cooperation: A systematic literature review and research agenda. Science and Public Policy, 45(5), 708-718, https://doi.org/10.1093/scipol/scy003

Corbae, D. ve Levine, R. (2018). Competition, stability, and efficiency in financial markets. Unpublished manuscript. http://www. ilsole24ore. com/pdf2010/Editrice/ILSOLE24ORE/ILSOLE24ORE/Online/_Oggetti_Embedded/Documenti/2018/0 8/25/Jackson-Corbae_Levine. pdf.

Çıtak, L. ve İltaş, Y. (2017). Ar - Ge yatııımlarının finansal performans üzerindeki etkisi ve BİST teknoloji endeksi firmalarının etkinliklerinin değerlendirilmesi. Mubasebe ve Finansman Dergisi, (76), 239-254.

Doanh Le, T., Phuong Thao Pham, D. ve Bach Le, T. (2019). The relationship between financial development and innovation: Empirical evidence from selected asian countries . Acta Universitatis Agriculturae et Silviculturae Mendelianae Brunensis, 67(1), 287-298.

Dünya Ekonomik Forumu (2017). Dünya Ekonomik Forumu Küresel Rekabetçilik. Endeksi 2016-2017 Baskess. Retrieved from

http://www.adaso.org.tr/WebDosyalar/K\%C3\%9CRESEL\%20REKABET\%C3\%87\%C4\%B0L\%C4\%B0K\% 20ENDEKS $\%$ C4\%B0\%20T\%C3\%9CRK\%C4\%B0YE.pdf 
Enkel, E., Gassmann, O. ve Chesbrough, H. (2009). Open RveD and open innovation: Exploring the phenomenon. RveD Management, 39(4), 311-317.

Erdem, E., Guloglu, B. ve Nazlioglu, S. (2010). The macroeconomy and turkish agricultural trade balance with the EU countries: Panel ARDL analysis. International Journal of Economic Perspectives, 4(1), 371.

Freitas, I. M. ve Rossi, F. (2013). Finding the right partners: Institutional and personal modes of governance of university-industry interactions. Research Policy, 42(1), 50-62.

Grosfeld, I. ve Tressel, T. (2002). Competition and ownership structure: Substitutes or complements? Evidence from the Warsaw Stock Exchange. Economics of Transition, 10(3), 525-551.

Hancıŏ̆lu, Y. ve Türkoğlu, S., (2017). Değişen rekabet anlayışı ve sürdürülebilirliğin işletmeler üzerindeki etkileri ve BİST Sürdürülebilirlik Endeksi'ndeki işletmelerin etkinliğinin araştırılması. Uluslararası İktisadi ve İdari İncelemeler Dergisi, (16. Ulusal İșletmecilik Kongresi Özel Say1), 237-252. do1: 10.18092/Ulikidince.316822

INSEAD (2007). The World's Top Innovators, The World Business/INSEAD Global Innovation Index. France.

Ekonomistler Platformu (2017). Küresel Rekabet Endeksi Değerlendirmesi. Retrieved from http://www.ekonomistler.org.tr/arsivler/7132.

Kayalvizhi, P. N. ve Thenmozhi, M. (2018). Does quality of innovation, culture and governance drive FDI?: Evidence from emerging markets. Emerging Markets Review. 34, 175-191. doi:https://doi.org/10.1016/j.ememar.2017.11.007

Leydesdorff, L. ve Meyer, M. (2006) Triple helix indicators of knowledge-based innovation systems. introduction to the special issue. Research Policy, 35(10), 1441-1450.

Metcalfe, J. S. (1994). Evolutionary economics and technology policy. The Economic Journal, 104(425), 931-944. doi: $10.2307 / 2234988$

Miynat, M. ve Gülden, O. (2016). Türkiye'de üniversite-sanayi işbirliğini sağlayan mekanizmalar ve işlevleri. 2. Uluslararasi Isletme ve Ekonomi Kongresi. Saraybosna.

Nicholas, T. (2008). Does innovation cause stock market runups? Evidence from the great crash. American Economic Review, 98(4), 1370-96.

Nickell, S. J. (1996). Competition and corporate performance. Journal of political economy, 104(4), 724-746.

Özcan, M., Ağırman, E. ve Yılmaz, Ö. (2014). Ar - Ge yatırımlarının hisse senedi getirisi üzerine etkisi: BISST teknoloji ve bilişim firmaları üzerine bir uygulama. Maliye Dergisi, 166, 139-158.

Öztürk, E. ve Göçmen Yağcılar, Ü. G. (2018). İnovasyon etkinliği ve finansal kısıtlar: Borsa İstanbul'da ampirik bir analiz. Visionary E-Journal/Vizyoner Dergisi, 9(22).

Pesaran, M. H. (2004). General diagnostic tests for cross section dependence in panels. Cambridge Working Papers in Economics No. 435, University of Cambridge, and CESifo Working Paper Series No. 1229.

Pesaran, M. H. (2007). A simple panel unit root test in the presence of cross-section dependence. Journal of Applied Econometrics, 22(2), 265-312.

Pesaran, M. H. ve Shin, Y. (1998). An autoregressive distributed-lag modelling approach to cointegration analysis. Econometric Society Monographs, 31, 371-413.

Pesaran, M. H., Shin, Y. ve Smith, R. P. (1999). Pooled mean group estimation of dynamic heterogeneous panels. Journal of the American Statistical Association, 94(446), 621-634.

Pradhan, R. P., Arvin, M. B., Nair, M., Bennett, S. E., Bahmani, S. ve Hall, J. H. (2018). Endogenous dynamics between innovation, financial markets, venture capital and economic growth: Evidence from Europe. Journal of Multinational Financial Management, 45, 15-34. doi:https://doi.org/10.1016/j.mulfin.2018.01.002

Türkiye Cumhuriyeti Sanayi ve Teknoloji Bakanlığ1 (2018). Public-University-Industry Cooperation. Retrieved from https://anahtar.sanayi.gov.tr/en/news/public-university-industry-cooperation/9607.

Sathappan, R. (2018). Exploring the possibility of co-operation between higher education and industries in Malaysia. Journal of Social Science Research, 12(1), 2525-2538.

Seppo, M., ve Lilles, A. (2012). Indicators measuring university-industry cooperation. Discussions on Estonian Economic Policy, 1, 204-225.

Solovjova, I., Rupeika-Apoga, R. ve Romānova, I. (2018). Competitiveness enhancement of international financial centres. European Research Studies Journal, 21(1), 5-17.

T.C. Gümrük ve Ticaret Bakanlı̆̆1 (2015). Küresel Rekabetçilik Raporu 2014 - 2015. Retrieved from http://risk.gtb.gov.tr/data/52c58a61487c8eca94a7c696/K\%C3\%BCresel\%20Rekabet\%C3\%A7ilik\%20Endeks i\%20Raporu\%202014-2015.pdf Erişim Tarihi: 14.01.2019

Tan, N., Wang, W., Yang, J. ve Chang, L. (2019). Financial competitiveness, financial openness and bilateral foreign direct investment. Emerging Markets Finance and Trade, 1-21. doi:10.1080/1540496X.2019.1590194

Topaloğlu, E, Yıkılmaz Erkol, A. ve Karakozak, Ö . (2017). Araştırma ve geliştirme yatırımlarının pay senedi getirileri ve pay senedi fiyat volatilitesine etkisi: Borsa İstanbul teknoloji bilişim firmaları üzerine bir uygulama. Nevşehir Hacı Bektas Veli Üniversitesi Sbe Dergisi, 7 (1), 1-13.

Türkmen, M. A. ve Aynaoğlu, Y. (2017). Küresel rekabet endeksi göstergelerinin küresel inovasyon endeksi üzerindeki etkisi. Business ve Management Studies: An International Journal, 5(4), 257-282.

Westerlund, J. (2007). Testing for error correction in panel data. Oxford Bulletin of Economics and Statistics, 69(6), 709748. 
Zhang, T. ve Matthews, K. (2019). Assessing the degree of financial integration in ASEAN-A perspective of banking competitiveness. Research in International Business and Finance, 47, 487-500. doi:https://doi.org/10.1016/j.ribaf.2018.09.009

\section{EXTENDED ABSTRACT}

The existence of a relationship between the economic indicators of the countries and the indices considered to be related to these indicators attracts the interest of the researchers. Undoubtedly, one of the important variables reflecting the general situation of the country's economy is the stock market index. Global competition, university-industry cooperation, global innovation and economic development are the concepts frequently encountered in the literature. The indices related to these concepts created by the world's leading institutions such as the World Bank, OECD and INSEAD (Institut Européen d'Administration des Affaires - European Institute of Business) are used in many scientific studies. The aim of this study is to investigate the effect of the competitiveness and innovation of the country on the stock market index. Competitiveness index (RE) was used to represent the competitiveness, and the innovation capacity index (İKE) and university industry cooperation index in research and development activities (ÜSİE) were used to represent innovation. In addition, per capita gross domestic product (GSYH) variable is included in the model's independent variables in order to take the effect of the size of the country's economy on the stock market index. In the study, data from 2007 to 2017 of G20 countries were used.

The data were obtained from the World Bank database and www.investing.com. The study was carried out in two stages. First, the relation between BE and RE and then the relationship between BE and IKKE, GSYH and ÜSİE variables were investigated. An important assumption to be investigated in panel data analysis is whether there is a cross-sectional dependence. Therefore, the cross-sectional dependence for variables was investigated with Pesaran (2004) test and found that all variables have crosssection dependence. Based on this result, all methods were used to take into account the cross-sectional dependence.

One of the important assumptions of panel data analysis, the stability was investigated by Pesaran (2007) test; İKE and ÜSİE variables were determined to be I(0); BE, RE and GSYH variables were determined to be I(1). Due to stationary levels, the relationship between BE and RE was investigated with the Westerlund panel cointegration test; The relationship between BE and IKKE, GSYH, and ÜSİE variables were investigated with the Panel ARDL test. According to the Westerlund panel cointegration test, there is no cointegration between $\mathrm{BE}$ and RE, the series are not related in the long term. The Wald test based on the ARDL model shows that there are long-term relationships between BE and IKE, GSYH, and ÜSIE variables. According to the panel ARDL model estimates, the Error Correction Term (ECT) has a value between 0 and -1 and is significant. This result shows that the error correction mechanism is working and that approximately $71 \%$ of the effect of external shocks is eliminated by error correction mechanism in a period. There is a long-term balance between variables. All of the long-term coefficients are significant at 5\% significance level. All coefficients are positive. In other words, increases in IKKE, GSYH, and ÜSIE increase BE in the long term. In the case of a standard unit change in the IKE, the BE changes 0.063 standard units in the same direction. A standard unit change in the ÜSIE will change BE 0.107 standard units in the same direction. A standard unit change in GDP changes BE 0.014 standard units in the same direction. As the variables are standardized and estimates are made, sizes of the explanatory variables' coefficient allow to use to compare the magnitudes of the explanatory variables on the dependent variable. According to these, the most effective variable on the BE is ÜSİE. Reflection of the science produced at the university to the society and its use in industry have positive effects on the country's economy. Developed and developing countries have turned universities from being merely educational institutions to units which contributing to the national economy through cooperation with industry. The development of the national economy can be achieved by increasing the university - industry cooperation. The PMG estimator used in the estimation of the panel ARDL model assumes that longterm coefficients are the same for all units and short-term coefficients and the constant term differ between the cross-sections. According to the short-term model estimates, the error correction term for countries other than Brazil, China, Mexico and the UK received significant and between expected values. For these countries, the error correction mechanism is working. The coefficient belongs to IKE is positive and significant for the United States, Argentina, Canada, Germany, India, Saudi Arabia and, Turkey. In the short term, the increases in the IKKE have positive effect on BE for these countries. IKKE has maximum influence on BE for Turkey. For Australia, China, France, Indonesia, Japan, Korea, Russia and England, coefficient of the İKE is negative and significant. In the short term, increases in the IKKE for these 
countries have a negative impact on BE. The maximum negative effect is seen for Brazil. For Argentina, China, Germany, Indonesia, Italy and Korea, the coefficient of ÜSIE is positive and significant. In the short term, the increases in the ÜSIE for these countries have a positive effect on BE. The maximum positive effect is seen for Italy. For Australia, Canada, France, India, Russia, Saudi Arabia, Turkey, the UK and, the US the coefficient belongs to ÜSIE is negative and significant. In the short term, the increases in the ÜSİE for these countries have a negative impact on BE. Maximum adverse effects seen for Turkey. For Canada, Indonesia, Russia, the United Kingdom and the United States, coefficient of GSYH is positive and significant. In the short term, the increases in GSYH for these countries have a positive impact on BE. The maximum positive effect is obtained for Indonesia. For Argentina, Australia, China, France, Germany, Italy, Japan, Korea, Saudi Arabia, GDP coefficient is negative and significant. Increases in GSYH for these countries have a negative impact on BE in short-term. The maximum negative effect is obtained for China. 